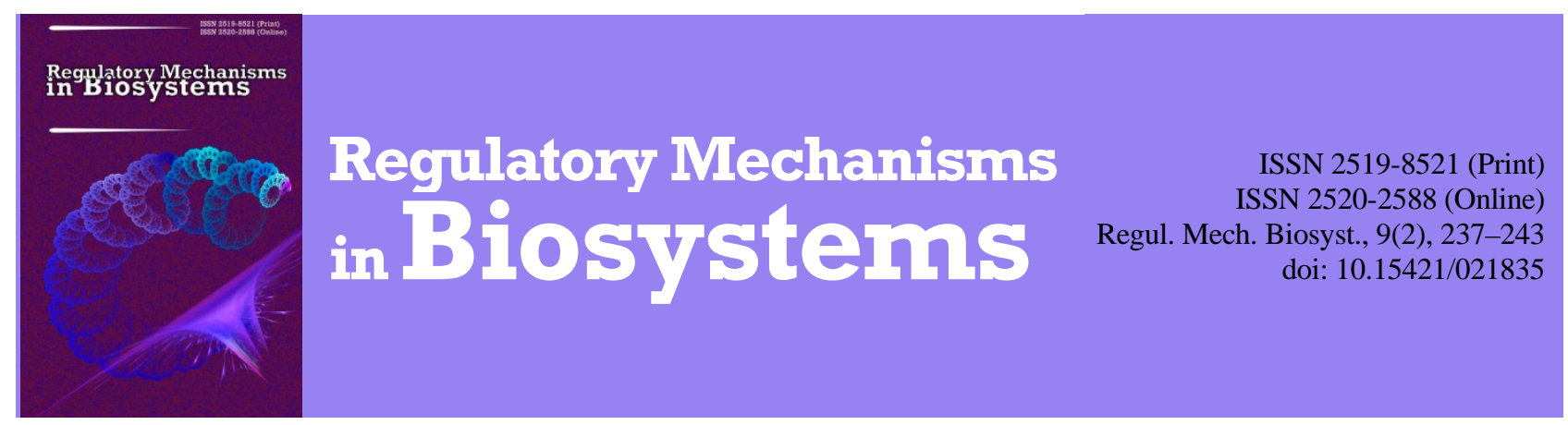

\title{
Ontogeny of Lobelia dortmanna genets in lake ecosystems
}

\author{
A. G. Lapirov*, E. A. Belyakov*, **, O. A. Lebedeva* \\ *I. D. Papanin Institute for Biology of Inland Waters RAS, Borok, Russia \\ **Cherepovets State University, Cherepovets, Russia
}

Article info

Received 14.02.2018

Received in revised form 27.03.2018

Accepted 02.04.2018

I. D. Papanin Institute for Biology of Inland Waters RAS, Borok,

Nekouz District, Yaroslavl Region, 152742, Russia.

Cherepovets State University, Lunacharsky Ave., 5 ,

Cherepovets, 162600, Russia.

Tel.: +7-920-109-05-42.

E-mail: panovaeg@mail.ru
Lapirov, A. G., Belyakov, E. A., \& Lebedeva, O. A. (2018). Ontogeny of Lobelia dortmanna genets in lake ecosystems. Regulatory Mechanisms in Biosystems, 9(2), 237-243. doi:10.15421/021835

Lobelia dortmanna $\mathrm{L}$. is one of the few rare, slowly growing relic plants occupying areas of the littoral zone of water bodies with low nutrient content and subject to wave action. Even in such difficult conditions, this plant successfully passes its entire life cycle, actively blossoms and fruits. That is why the peculiar features of the individual development of this plant in various geographical conditions is a matter of great interest. For the first time, this study considers in detail the ontogeny of the genet of $L$. dortmanna in oligotrophic lakes of Tver oblast. Detailed characteristics of the following age stages of individuals are given: resting seeds, seedlings, juvenile, young and adult vegetative, latent generative, middle-aged and old generative and quasisenile plants. It is shown that the transition to the juvenile age stage occurs at the end of the first year of life, the virginile age stage lasts two years, and the generative stage of development occurs in the fourth year of life. The change in the growth pattern of the rosette main shoot of Lobelia, from orthotropic to anisotropic, occurs in the second year of life. The establishment and further development of the generative organs of the plant and associated change in the growth of the main shoot from monopodial to simpodial occurs in the fourth year of life. At the same time, the branching of the main shoot begins by formation in the axils of the uppermost assimilating leaves (the last in front of the apical inflorescence) - 1-2 lateral rosette shoots. These are future ramets (vegetative diasporas), which ensure, in the future, the vegetative reproduction of the individual and spread to new territories. Taking into account that in lakes of Tver oblast, Lobelia groupings form dense aggregated clusters on the bottom, the transition of individuals to a quasisenile age state (in the fifth year of life) enables them to rejuvenate and survive after the death of the maternal shoot. The formation and further development of rosette lateral shoots allows the plant to re-occupy the territory via vegetative or seed propagation. Complete morphological disintegration (vegetative reproduction) occurs in the fifth year of life. The genets' ontogeny is completed by the formation of a compact clone from the detached lateral rosette shoots.

Keywords: individual development; periods of ontogenesis; age states of individuals; oligotrophic lakes

\section{Онтогенез генеты лобелии Дортманна (Lobelia dortmanna) в озерных экосистемах}

\author{
А. Г. Лапиров*, Е. А. Беляков ****, О. А. Лебедева* \\ *Институт биологии внутренних вод имени И. Д. Папанина РАН, Борок, Россия \\ **Череповеиякий государственный университет, Череповеи, Россия
}

Лобелия Дортманна (Lobelia dortmanna L.) - одно из немногих редких, медленно растущих реликтовых растений, занимающих участки литоральной зоны водоемов с низким содержанием питательных веществ и подверженных волновому действию. Даже в таких сложных условиях это растение успешно проходит весь жизненный цикл, активно цветет и плодоносит. Именно поэтому пристальный интерес вызывают особенности индивидуального развития этого растения в различных географических условиях. В работе впервые подробно рассмотрен онтогенез генеты лобелии Дортманна в олиготрофных озерах Тверской области. Дана развернутая характеристика следующим возрастным состояниям особей: покоящиеся семена, проростки, ювенильные, молодые и взрослые вегетативные, скрытогенеративные, средневозрастные и старые генеративные и квазисенильные растения. Показано, что переход в ювенильное возрастное состояние наблюдается в конце первого года жизни, виргинильное возрастное состояние длится в течение двух лет, а генеративный этап развития наступает на четвертый год жизни. Смена характера роста розеточного главного побега лобелии с ортотропного на анизотропный происходит на втором году жизни. Заложение и дальнейшее развитие генеративных органов растения и, связанная с этим, смена нарастания главного побега с моноподиального на симподиальное осуществляется на четвертом году жизни растения. В это же время начинается ветвление главного побега за счет формирования в пазухах самых верхних ассимилирующих листьев (последних перед верхушечным соцветием) одного - двух боковых розеточных побегов. Это будущие раметы (вегетативные диаспоры), обеспечивающие, в дальнейшем, вегетативное размножение особи и захват новых территорий. Учитывая то, что в озерах Тверской области группировки лобелии образуют на дне водоемов плотные агрегированные скопления, переход особей в квазисенильное состояние (на пятом году жизни) дает возможность им омолодиться и выжить 
после гибели материнского побега. Формирование и дальнейшее развитие розеточных боковых побегов позволяют растению вновь занять территорию вегетативным или семенным путем. Полная морфологическая дезинтеграция (вегетативное размножение) наступает на пятом году жизни. Онтогенез генеты завершается образованием компактного клона из отделившихся боковых розеточных побегов.

Ключевые слова: индивидуальное развитие; периоды онтогенеза; возрастные состояния особей; олиготрофные озера

\section{Введение}

Среди разнообразных направлений биоморфологических исследований «онтогенетическое направление пополняет научное знание представлениями об изменениях жизненных форм в онтогенезе» (Savinykh and Cheryomushkina, 2015, p. 660). В этой связи несомненный интерес вызывает изучение онтогенеза редких водных растений, таких как Lobelia dortmanna Linnaeus, 1753. Это растение, вместе с Isoetes lacustris Linnaeus (1753), Isoetes echinospora Durieu, 1861, Subularia aquatica Linnaeus (1753) представляет собой группу видов, характерных для литоральной зоны пресноводных олиготрофных озер с мягкой водой (Pulido et al., 2012; Markov, 2017; Lewicka-Rataj et al., 2018).

Сведения по онтогенезу лобелии Дортманна в отечественной литературе нами не обнаружены, а в зарубежных источниках их крайне мало. Среди них работы английского автора Woodhead (1951), представившего рисунки и описания начальных стадий развития проростка, и польского исследователя Szmeja (1987a, 1987b, 1994), выделившего в онтогенезе L. dortmanna пять стадий и показавшего схемы прохождения жизненного цикла этого растения в открытых (подверженных волновому действию) и защищенных местообитаниях. При этом в данных работах отсутствуют подробные описания онтогенетических (возрастных) состояний.

Заметим также, что исследование особенностей онтогенеза лобелии Дортманна является продолжением серии наших работ, связанных с этим реликтовым видом. Ранее нами уже были изучены особенности прорастания семян этого растения в лабораторных условиях, а также его биоморфология и ритм сезонного развития в олиготрофных озерах Тверской области (Lebedeva \& Belyakov, 2016; Lapirov et al., 2017).

Исходя из вышеизложенного, цель работы - изучить онтогенез лобелии Дортманна из зачатка генеративного происхождения в олиготрофных озерах Тверской области.

\section{Материал и методы исследований}

Материал собран в 2014-2016 гг. в естественных популяциях L. dortmanna на озерах Сиг (окрестности деревень Куряево $57^{\circ} 01^{\prime 2} 28,4^{\prime \prime} \mathrm{N}, 33^{\circ} 06^{\prime} 36^{\prime \prime}$ Е, Буковичи - 57 $03^{\prime} 15^{\prime \prime} \mathrm{N}, 33^{\circ} 11^{\prime} 02^{\prime \prime}$ Е и Краклово - 57 $01^{\prime} 28^{\prime \prime} \mathrm{N}, 33^{\circ} 06^{\prime} 38^{\prime \prime}$ Е) и Бельском (близ д. Белое -

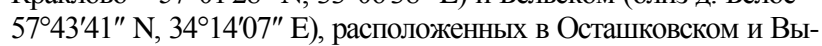
шневолоцком районах Тверской области. Исследования в течение трех лет в одних и тех же местообитаниях позволили охватить в целом весь вегетационный сезон с ранней весны (май) до поздней осени (сентябрь - октябрь). Как мы писали ранее (Lapirov et al., 2017), на исследованных озерах это растение занимает глубины от $0,2(0,3)$ до 1,2 и более метров и произрастает на песчаном или песчаном с наилком грунтах. Растет в виде отдельных экземпляров либо небольших групп или обширных пятен (проективное покрытие до 100\%). Группировки данного вида сосредоточены в основном в тростниковых зарослях либо на защищенных (реже не защищенных) от волнового действия открытых пространствах.

Начальные этапы онтогенеза прослежены нами как в природных, так и лабораторных условиях. В последнем случае семена проращивали в люминостате (освещенность 1200-1500 лк, фотопериод $9 / 15$, температура $-+23{ }^{\circ} \mathrm{C}$ ) в чашках Петри на фильтровальной бумаге, увлажненной отстоявшейся водопроводной водой. Во всех вариантах опытов использовали три чашки Петри по 50 семян в каждой.

В процессе работы проводили тщательный морфологический анализ надземной и подземной сферы растений. У них измеряли длину и ширину наибольшего листа, максимальную длину корней, цветоноса, длину и диаметр розеточной части побега, емкость верхушечной почки побега, подсчитывали количество придаточ- ных корней, листьев и цветоносов. При этом относили растения к тому или иному возрастному состоянию на основании комплекса наиболее существенных качественных признаков, среди которых «способ питания (связь с семенем), наличие зародышевых, ювенильных или взрослых структур, способность особей к семенному или вегетативному размножению, соотношение и интенсивность этих процессов; соотношение процессов новообразования и отмирания у особи, степень сформированности у особи основных признаков биоморфы» (Cenopopulation of plants..., 1976, p. 17). Дополнительно, для анализа морфологических признаков растений различных возрастных состояний, использовали гербарные материалы ИБВВ РАН (IBIW), а также более ранние данные (1974 г.), полученные первым автором при изучении растительного покрова оз. Бельское. Для исследования основных морфометрических показателей растений применяли бинокулярные микроскопы МБС-10 и МСП-2, снабженные микрометрическими шкалами. Изучено около 100 особей различных возрастных состояний. В тексте работы и в таблицах данные представлены в виде $\mathrm{x} \pm \mathrm{SD}$.

\section{Результаты}

У лобелии Дортманна нами выделены и описаны слудющие периоды онтогенеза и возрастные состояния особей, формирующихся из семени.

Период первичного покоя (латентный период). Представлен покоящимися семенами. Они очень мелкие, «пылевидные», правильной эллиптической формы, длиной $0,4-0,6$ мм и шириной 0,3-0,4 мм. Семенная оболочка блестящая темно- либо светло-коричневая с неровной, «бугристой» скулыптурой.

Прегенеративный (виргинильный период). Проростки. Данное возрастное состояние в лабораторных условиях длится около 30 суток. Характеризуется появлением всех основных органов, ортотропным нарастанием побеговой оси и началом ее утолщения.

Период набухания семян длится до 7 суток. Затем семенная крышечка (operculum), к которой примыкает конец зародышевого корешка, постепенно начинает отделяться от семени. Такие особые образования, по-видимому, являются своеобразной защитой апикальной части первичного корня в самом начале прорастания. В процессе прорастания крышечка выдавливается зародышевым корешком, дальнейший рост которого способствует разрыву покровов семени (на 5-6 частей, рис. $1 a, b$ ). Зародышевый корешок проростка утолщенный, слегка загнутый, белого цвета. У отдельных проростков отмечено наличие на нем очень редких корневых волосков. Гипокотиль тонкий, верхняя часть его светло-зеленая. Место перехода корня в гипокотиль, так называемая «корневая шейка», иногда очень слабо опушена. Семядоли вслед за гипокотилем постепенно освобождаются от семенной оболочки, выносятся на поверхность грунта, начиная выполнять функцию первых ассимилирующих листьев (рис. 1c). Обе пластинки семядолей овально-ланцетовидные, цельнокрайние, срастаются в основании, прикрывая зародышевую почечку. Через 5-7 суток у проростка развивается первый настоящий линейный лист (рис. 1d), следом за ним, через двое суток - второй, плотно прижатый к первому. С появлением первых ассимилирующих листьев наблюдается начало формирования розеточного участка побега. Появление первого (иногда второго) листа нередко сопровождается формированием первого гипокотилярного придаточного корня. Чаще он развивается в базальной части гипокотиля, реже - при основании семядолей. Полностью сформированный проросток представляет собой одноосное моноподиально и ортотропно нарастающее розеточное растение с двумя настоящими ассимилирующими листьями. Главный корень продолжает функционировать наряду с первым придаточным. В лабораторных условиях на этой стадии развития 
проростки погибали.

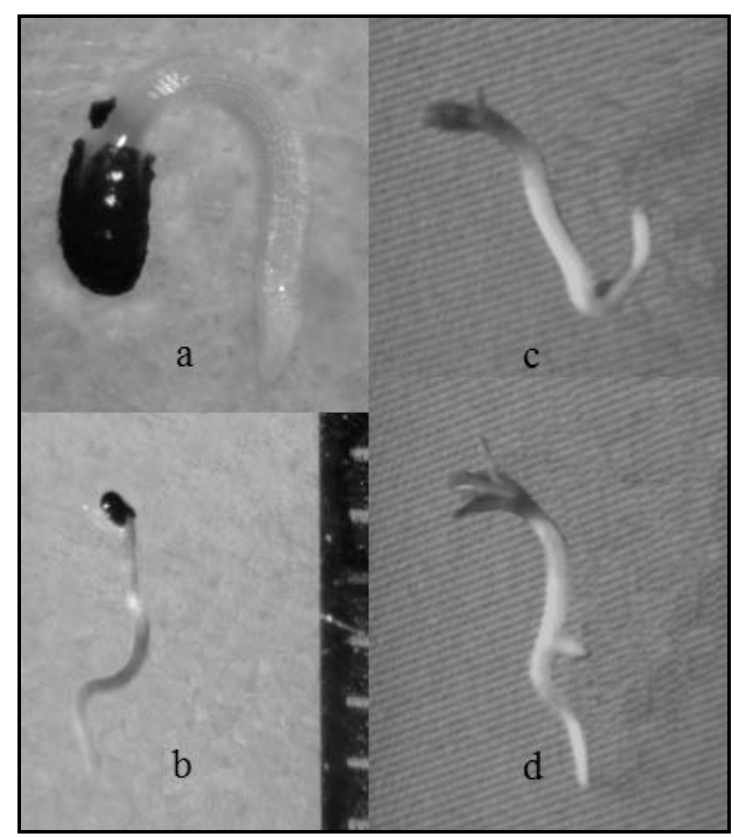

Рис. 1. Проростки L. dortmanna в лабораторных условиях: $a-d-$ стадии развития проростка

В природных популяциях проростки обнаружены нами во второй декаде мая и в конце августа - начале сентября (спустя 4 5(6) недель после начала диссеминации), между листьями либо корнями материнского розеточного побега (рис. $2 a$ ) или плавающими на поверхности воды. Все морфологические показатели проростков, развивающихся в природных водоемах, отличались от лабораторных большими размерами и числом структурных элементов (табл. 1 , рис. $2 b$ ). Кроме того, на побеге еще сохранялись остатки семядольных листьев.

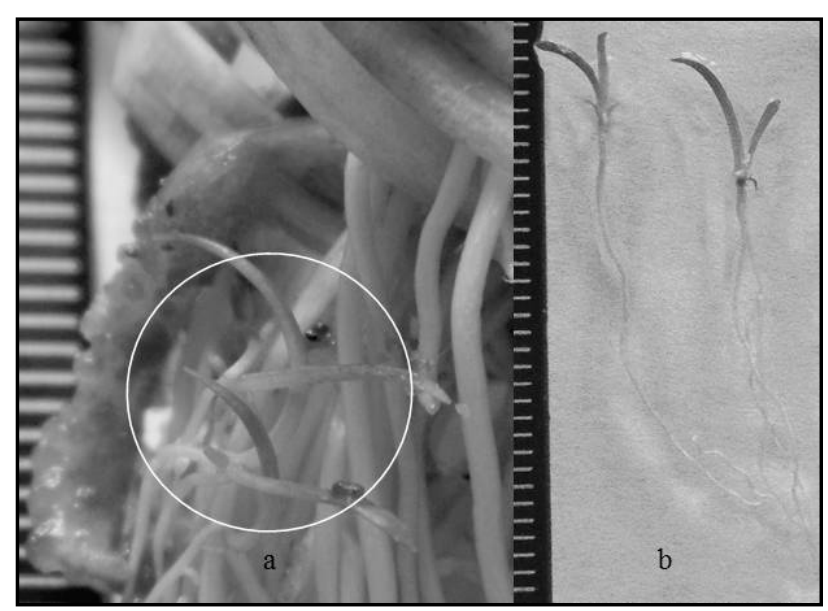

Рис. 2. Проростки $L$. dortmanna $(b)$ на корнях материнского растения $(a)$ в природных условиях (очерчены эллипсом)

Дальнейшие наблюдения за ходом онтогенеза проводили в естественных местах произрастания растений.

Ювенильные растения. Переход растений в ювенильное онтогенетическое состояние происходит в конце первого вегетационного сезона и характеризуется увеличением числа ассимилирующих листьев и стеблеродных придаточных корней (табл. 2, рис. 3a). На концах последних отмечены специфические утолщения, связанные с наличием арбускулярно-везикулярной микоризы. Отдельные придаточные корни ветвятся до $\mathrm{n}+1$ порядка. В два раза (при сравнении с проростками) возрастает длина и диаметр розеточного участка побега (табл. 2). При этом в фазе третьего асси- милирующего листа и четырех придаточных корней у отдельных растений главный корень начинал отмирать. Листья ювенильных растений по форме соответствуют листьям взрослого растения. Они линейно-ланцетные, полые, вальковатые, с отогнутой апикальной частью и расширенным основанием. Верхняя часть листовой пластинки ярко-зеленая, а расширенное основание листа лишено окраски. В этом возрастном состоянии растения зимуют.

Таблица 1

Основные морфологические показатели проростков L. dortmanna в лабораторных и природных условиях $(\mathrm{n}=12, \mathrm{x} \pm \mathrm{SD})$

\begin{tabular}{lcc}
\hline \multirow{2}{*}{ Морфологические показатели } & \multicolumn{2}{c}{ Размеры органов, мм } \\
\cline { 2 - 3 } & $\begin{array}{c}\text { лабораторные } \\
\text { условия }\end{array}$ & $\begin{array}{c}\text { природные } \\
\text { условия }\end{array}$ \\
\hline Длина семядолей & $0,66 \pm 0,10$ & $1,78 \pm 0,14$ \\
Ширина семядолей & $0,20 \pm 0,04$ & $0,45 \pm 0,05$ \\
Длина гипокотиля & $1,98 \pm 0,49$ & - \\
Диаметр гипокотиля & $1,80 \pm 0,03$ & - \\
Длина главного корня & $1,16 \pm 0,13$ & $12,0 \pm 4,50$ \\
Длина первого придаточного корня & $0,24 \pm 0,09$ & $3,75 \pm 0,75$ \\
Длина первого ассимилирующего листа & $0,14 \pm 0,05$ & $6,50 \pm 0,50$ \\
Ширина первого ассимилирующего листа & $0,12 \pm 0,03$ & $0,50 \pm 0,00$ \\
Длина второго ассимилирующего листа & $0,20 \pm 0,01$ & $4,50 \pm 0,50$ \\
Ширина второго ассимилирующего листа & менее 0,20 & $0,38 \pm 0,04$ \\
Длина розеточного участка побега & $0,25 \pm 0,05$ & $0,93 \pm 0,08$ \\
Диаметр розеточного участка побега & $0,25 \pm 0,05$ & $0,95 \pm 0,05$ \\
\hline
\end{tabular}

Примечание: «-»-данный элемент структуры выражен слабо.

\section{Таблица 2}

Основные морфологические показатели растений L. dortmanna в ювенильном возрастном состоянии $(\mathrm{n}=12, \mathrm{x} \pm \mathrm{SD})$

\begin{tabular}{lc}
\hline \multicolumn{1}{c}{ Морфологические показатели } & $\begin{array}{c}\text { Размеры } \\
\text { органов }\end{array}$ \\
\hline Длина розеточного участка побега, мм & $1,83 \pm 0,22$ \\
Диаметр розеточного участка побега, мм & $1,83 \pm 0,22$ \\
Число ассимилирующих листьев, шт. & $3,01 \pm 0,01$ \\
Число придаточных корней, шт. & $4,02 \pm 0,01$ \\
Максимальная длина придаточных корней, мм & $29,7 \pm 5,8$ \\
Максимальная длина ассимилирующих листьев, мм & $18,0 \pm 1,3$ \\
Максимальная ширина ассимилирующих листьев, мм & $1,01 \pm 0,01$ \\
Длина главного корня, мм & $47,7 \pm 1,8$ \\
\hline
\end{tabular}

Второй год жизни. Виргинильные (молодые вегетативные) растения второго года жизни. Характеризуются появлением основных черт, типичных для взрослых вегетативных растений. Первичный моноподиально нарастающий розеточный побег состоит из участка прошлого года, несущего коричневые остатки листьев и нынешнего года. На последнем существенно возрастает число ассимилирующих листьев и придаточных корней, а также увеличиваются их линейные размеры (табл. 3 , рис. $3 b$ ). Отмирание сформированных ранее листьев и рост новых, а также формирование большого числа стеблеродных придаточных корней вносит изменения в структуру базальной части побега. Она увеличивается в длину и утолщается в диаметре (табл. 3), темнеет и втягивается корнями в плотный песчаный грунт. В результате этого розеточный участок побега меняет характер роста с ортотропного на анизотропный. Емкость верхушечной почки побега - 2-3 листовых зачатка. Подобный характер роста сохраняется до конца вегетационного сезона.

Третий год жизни. Виргинильные (взросльее вегетативные) растения третьего года жизни. Несмотря на то, что основные морфологические параметры этих растений (табл. 3, рис. 3c) в начале вегетационного сезона существенно не отличаются от предыдущей группы, у них в 1,5-3,0 раза возрастает количество ассимилирующих листьев и придаточных корней на участке побега нынешнего года, в 2 раза - емкость верхушечной почки главного побега (табл. 3). При этом у последнего отмирает участок первого года жизни. В течение вегетационного сезона у растений наблюдается дальнейший рост основных параметров вегетативной сферы растений: максимальной длины и ширины листьев $(5,3 \pm 0,3$ и $0,3 \pm 0,0 \mathrm{~cm}$, соответственно), максимальной длины придаточных корней $(9,1 \pm 1,2$ см), общего числа ассимилирующих листьев и 
придаточных корней $(28,4 \pm 6,1$ и $96,0 \pm 28,4)$, а также емкости верхушечной почки главного побега $(7,0 \pm 0,8)$. Возрастает длина и диаметр розеточной части побега нынешнего года $(1,1 \pm 0,3$ и $0,4 \pm 0,1$, соответственно). Анизотропный характер роста и моноподиальный тип нарастания главного побега сохраняются.

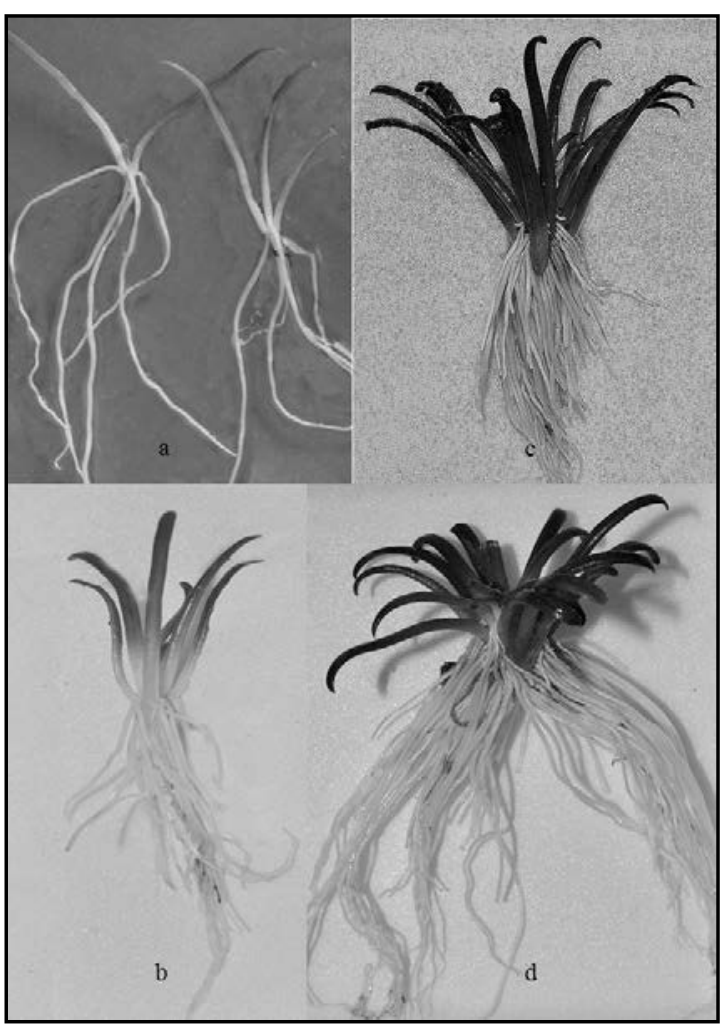

Puc. 3. L. dortmanna в ювенильном (a), молодом вегетативном (второй год жизни) (b), взрослом вегетативном (третий год жизни)

(c) и скрытогенеративном (d) возрастных состояниях

Четвертый год жизни. Генеративный период онтогенеза. Скрытогенеративные растения. Переход растений в скрытогенеративное онтогенетическое состояние отражает наступление генеративного периода онтогенеза (рис. $3 d$ ). Важнейшей отличительной особенностью растений в это время является не только наличие внешне незаметного верхушечного соцветия, длиной $0,9 \pm 0,3 \mathrm{~cm}$, но и почек, расположенных в пазухах одного-трех самых верхних ассимилирующих листьев побега нынешнего года. Их длина - от 0,1 до 0,6(0,9) мм, емкость 1-4 листовых зачатка. Почки (1-2), трогаются в рост без периода покоя, формируя боковые розеточные побеги, несущие 3-4 ассимилирующих листа. Емкость верхушечных почек боковых побегов - 7-8 листовых зачатков. С момента закладки генеративных органов нарастание главного побега становится симподиальным. Начинает постепенно перегнивать участок побега третьего года жизни. Биометрические характеристики этих растений представлены в таблице 4.

Средневозрастные генеративные растения. У подавляющего большинства растений участок главного побега третьего года жизни на этом этапе отмирает полностью. У растений сохраняется только участок побега нынешнего года. У значительного числа растений на большинстве придаточных корней (ветвящихся до второго порядка) имеются вздутия, представляющие собой везикулярно-арбускулярную микоризу. С ростом верхушечного соцветия, достигающего длины 91,0 $\pm 16,4 \mathrm{~cm}$, растение становится полурозеточным (рис. $4 a, b$ ). Наблюдается дальнейшее развитие боковых розеточных побегов (1-2), которые несут до $14,4 \pm 6,5$ листьев (длиной $4,5 \pm 1,2$ и шириной $0,3 \pm 0,0$ см) и $28,6 \pm 12,2$ придаточных корней. Емкость их верхушечной почки - 7-8 листовых зачатков. Биометрические характеристики этих растений представлены в таблице 4.

У старых генеративных растений процессы отмирания преоб- ладают над процессами новообразования (рис. 4c). Отгнивает верхушечное соцветие. На главном побеге (представленном только участком нынешнего года), несущем 1-2 розеточных боковых побега, погибает значительная часть придаточных корней (их количество снижается практически в два раза - $95 \pm 8$ ) и ассимилирующих листьев $(17,5 \pm 3,3)$. В таком виде растения зимуют.

\section{Таблица 3}

Основные биометрические показатели растений L. dortmanna в виргинильном возрастном состоянии $(\mathrm{n}=12, \mathrm{x} \pm \mathrm{SD})$

\begin{tabular}{lcc}
\hline \multirow{2}{*}{ Морфологические показатели } & \multicolumn{2}{c}{ Возрастное состояние } \\
\cline { 2 - 3 } & $\begin{array}{c}\text { молодые } \\
\text { вегетативные }\end{array}$ & $\begin{array}{c}\text { взрослые } \\
\text { вегетативные }\end{array}$ \\
\hline Число листьев, шт. & $6,01 \pm 1,01$ & $9,70 \pm 2,11$ \\
Число придаточных корней, шт. & $16,00 \pm 1,02$ & $41,80 \pm 12,40$ \\
Емкость верхушечной почки & $2,03 \pm 1,02$ & $4,63 \pm 0,57$ \\
(число листовых зачатков) & $30,50 \pm 0,50$ & $27,80 \pm 2,74$ \\
Длина листьев, мм & $2,50 \pm 0,01$ & $2,01 \pm 0,36$ \\
Ширина листьев, мм & $52,50 \pm 7,50$ & $70,70 \pm 5,52$ \\
Длина придаточных корней, мм & $4,91 \pm 1,90 /$ \\
Длина/диаметр розеточной час- & $6,01 \pm 1,01 /$ & $2,98 \pm 1,40$ \\
ти побега нынешнего года, мм & $2,90 \pm 1,01$ & $3,45 \pm 2,05 /$ \\
Длина/ диаметр розеточной & $3,02 \pm 2,01 /$ & $2,90 \pm 1,01$ \\
части побега прошлого года, мм & $1,82 \pm 0,32$ & (второго года) \\
\hline
\end{tabular}

\section{Таблица 4}

Основные биометрические показатели растений L. dortmanna в генеративном периоде онтогенеза $(\mathrm{n}=15, \mathrm{x} \pm \mathrm{SD})$

\begin{tabular}{lcc}
\hline \multirow{2}{*}{ Морфологические показатели } & \multicolumn{2}{c}{ Возрастное состояние } \\
\cline { 2 - 3 } Число листьев, шт. & $18,6 \pm 1,9$ & $23,3 \pm 3,3$ \\
Число придаточных корней, шт. & $91,0 \pm 16,4$ & $153,2 \pm 25,8$ \\
Длина листьев, мм & $39,4 \pm 2,9$ & $51,0 \pm 3,7$ \\
Ширина листьев, мм & $2,80 \pm 0,32$ & $3,80 \pm 0,27$ \\
Длина придаточных корней, мм & $80,4 \pm 19,4$ & $107,0 \pm 21,0$ \\
Длина / диаметр розеточной части & $22,00 \pm 3,02$ / & $18,00 \pm 8,03$ / \\
побега нынешнего года, мм & $3,20 \pm 0,32$ & $4,01 \pm 1,01$ \\
Длина / диаметр розеточной части & $4,91 \pm 1,90$ / & \\
побега прошлого года, мм & $2,98 \pm 1,40$ & - \\
& (третьего года) \\
\hline
\end{tabular}

Пятый год жсини. Постгенеративный период онтогенеза. Характерная особенность этого периода развития - переход растений в начале вегетационного сезона в квазисенильное состояние. Квазисенильность определяется как «явление морфологической имитации сенильности, возникающее у растений в фитоценотически неблагоприятных условиях» (Smirnova et al., 1984). По внешнему виду квазисенильные растения представляют собой «двуили однорогую вилку», состоящую из участка главного побега прошлого года, несущего перегнившие остатки ассимилирующих листьев, и одного или двух розеточных побегов второго порядка ветвления. Именно за счет их развития осуществляется омоложение особи. Рисунок квазисенильного растения представлен в опубликованной ранее работе (Lapirov et al., 2017).

У подавляющего большинства растений развивается, как правило, один боковой розеточный побег. У единичных растений - два, при этом один, как правило, опережает в своем развитии другой. По-видимому, у квазисенильные растения, крайне редко, способны одновременно достигать генеративного состояния. Подобное явление отмечено во второй декаде июля 2014 г. у единичных растений на оз. Бельское. При этом боковые побеги второго порядка, связанные с главным побегом, цвели (длина цветоносов 50-60 см) и имели хорошо развитые боковые розеточные побеги третьего порядка (по отношению к главному побегу), длиной 0,30,4 см, несущие 4-5 листьев. Емкость их верхушечной почки 5-8 листовых зачатков. Однако у большинства растений дальнейшее развитие претерпевает, как правило, один боковой побег второго порядка, редко - два. Их цветения в текущем году мы не наблюдали. В середине (конце) вегетационного сезона происходит полная дезинтеграция растений (за счет разрушения участка главного 
побега прошлого года), приводящая к формированию компактного клона из отделившихся боковых побегов. На этом онтогенез

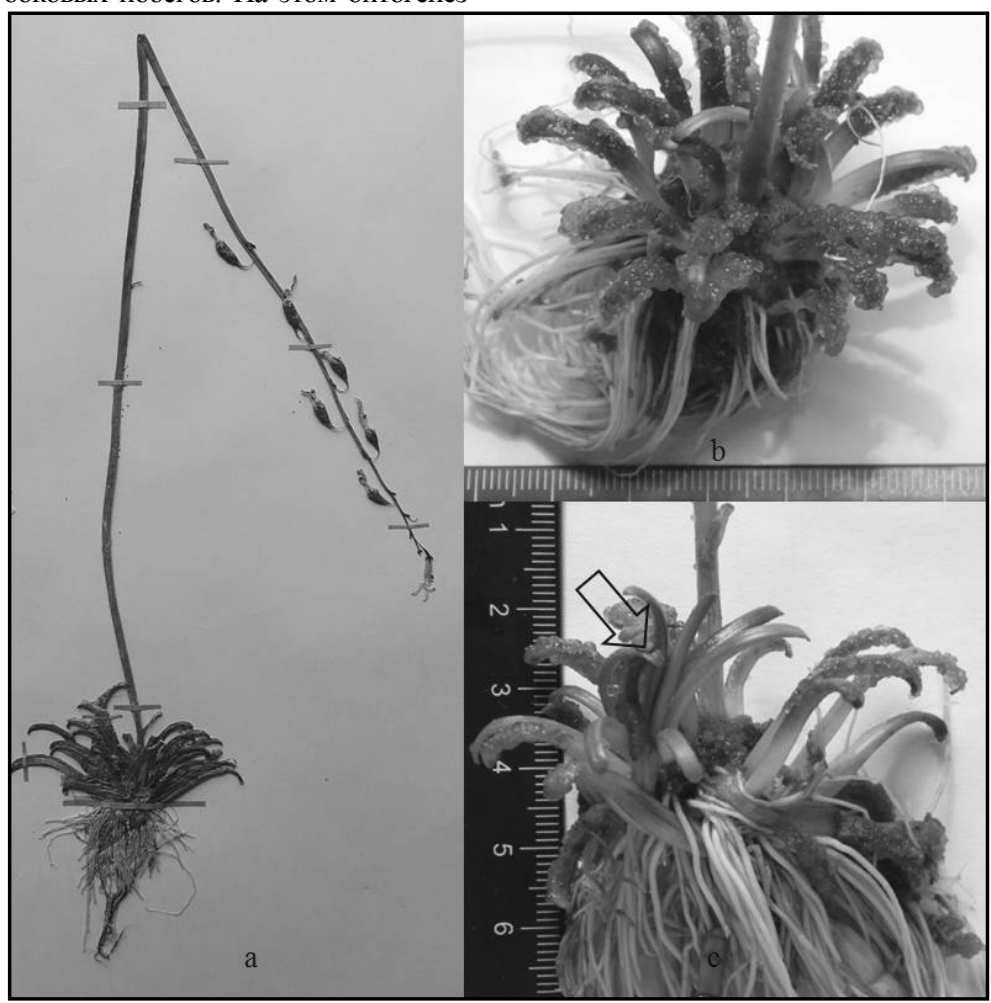

Рис. 4. Средневозрастное генеративное $(a, b)$ и старое генеративное (c) растение L. dortmanna: стрелкой указан развивающийся побег $\mathrm{n}+1$ порядка ветвления

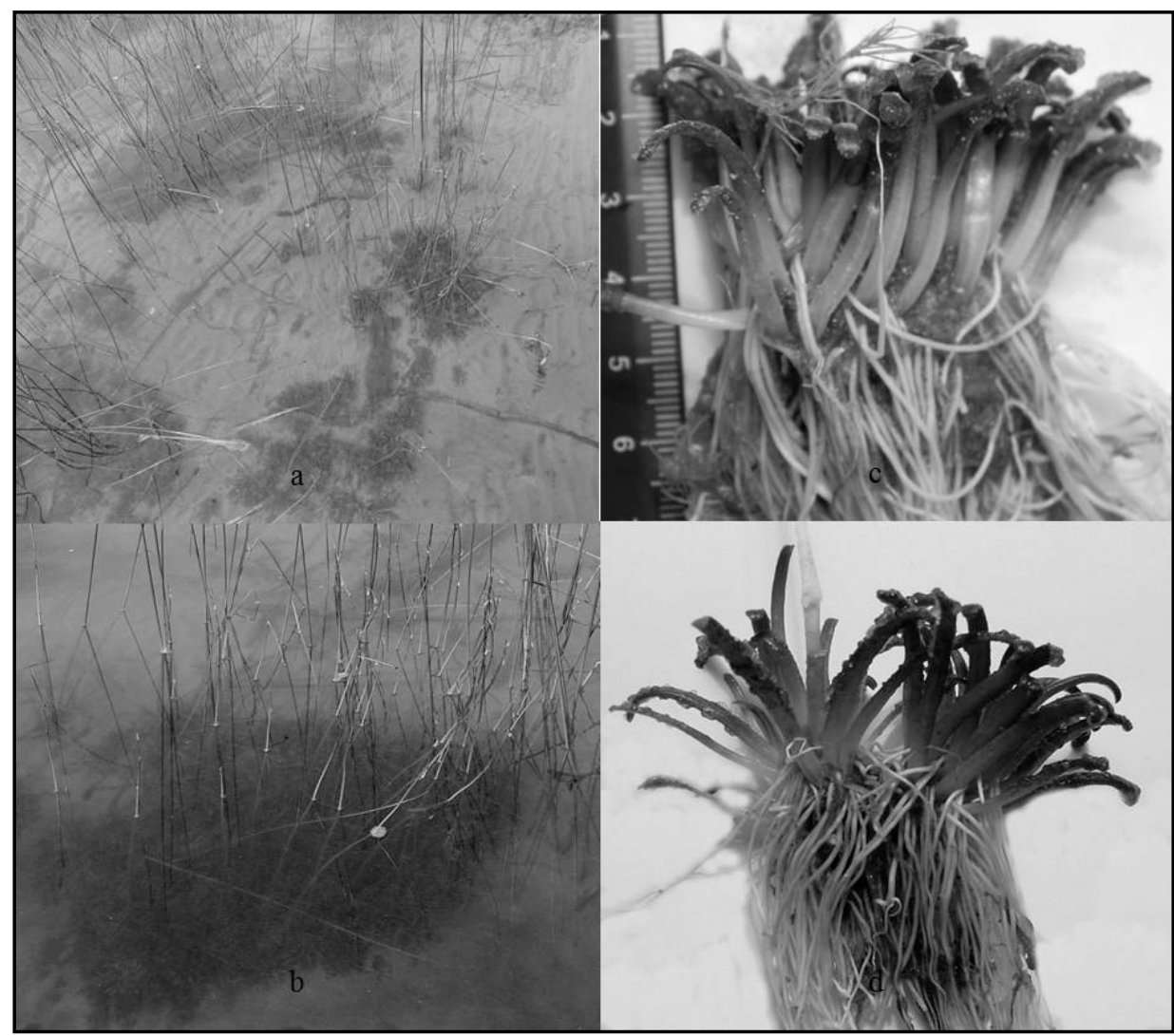

Рис. 5. Агрегации L. dortmanna в озерах Тверской области $(a, b)$ и их фрагменты $(c, d)$

\section{Обсуждение}

Как и на маленьком мелководном олиготрофном полимикти-

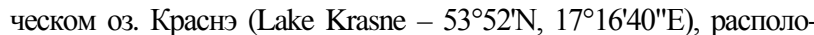

женном в Северной Польше (Szmeja, 1994), в исследованных озеpax Тверской области онтогенез лобелии Дортманна из зачатка генеративного происхождения длился в течение пяти лет. При этом польский автор отмечает, что как в условиях, подверженных 
волновому действию, так и защищенных условиях, онтогенез этого вида может длиться в течение четырех лет (Szmeja, 1994). Полагаем, что и в наших условиях подобный «сценарий» развития также возможен.

При этом Szmeja (1994) отмечает, что в оз. Краснэ в обоих типах местообитаний (защищенных и открытых) гибель проростков составляет довольно значительную величину (85,1-99,1\%). Поэтому вполне объяснима отмеченная нами в лабораторных условиях гибель растений на самых ранних, наиболее уязвимых стадиях развития (проростки). Заметим, что полная морфологическая характеристика семян, а также особенности их прорастания представлены в наших предыдущих статьях (Lebedeva \& Belyakov, 2016; Lapirov et al., 2017). Нами показано, что переход растений в ювенильное онтогенетическое состояние происходит в конще первого вегетационного сезона. Однако по данным Szmeja (1987b) переход в это возрастное состояние возможен еще в весенний период. Указанный автор связывает это с более быстрым ростом проростков на илистых и песчано-илистых участках дна, чем на песчаных. Существовать в подобных условиях молодым растениям помогает наличие на придаточных корнях арбускулярно-везикулярной микоризы (Nielsen et al., 2004), отмеченное нами ранее (Lapirov et al., 2017). По-видимому, и в наших условиях такая группа растений в весенний период может присутствовать, учитывая то, что нормально развитые проростки обнаружены нами на песчаном с наилком грунте уже 11.05.2016 года. При этом заметим, что смертность в популяции ювенильных растений, даже в защищенных местах обитания, достигает 26,4\% (Szmeja, 1994).

На второй год развития смена двух последующих возрастных состояний (имматурного и виргинильного) у лобелии происходит достаточно быстро. Мы поддерживаем точку зрения о том, что «выделение имматурных и виргинильных растений представляет болышие трудности» (Cenopopulation of plants, 1976, p. 19) и, поэтому, «некоторыми авторами [эти возрастные состояния] объединяются в одно» (ibid). Поэтому в данной работе мы выделяем только виргинильное возрастное состояние.

К сожалению, краткость и размытость характеристик, которые даны различным возрастным состояниям особей лобелии (Szmeja, 1987a), не позволяют провести их качественное сравнение с нашими данными. На основании описаний периода зрелости (mature state): «накопление корневой системы, неразветвленное, плагиотропное корневище 2-4 см в длину, и полностью развитая розетка из 15-25 листьев («а bunched root system, unbranched, а plagiotropic rhizome 2-4 cm long, and a fully-developed, 15-25-leaved rosette»)» (ibid, p. 18) можно предположить, что данный исследователь имел в виду (в нашем понимании) взрослые вегетативные растения. Отличия в размерных величинах между нашими и польскими данными, по-видимому, связаны с различиями экологических условий в местах произрастания растений. В другой работе (Szmeja, 1987b, p. 537) этот же автор, давая характеристику зрелых особей, причисляет к ним и генеративные растения («Морфологически зрелые особи, т. е. зрелые и генеративные» («Morphologically mature individuals, i.e., mature and generative»)). В данном случае, в нашем понимании, автор имел в виду скрытогенеративные растения, не имеющие внешне видимых генеративных органов. Поэтому эти растения внешне напоминают взрослые вегетативные.

Анализ структуры различных популяций лобелии в озерах Доброгощ (Lake Dobrogoszcz) и Великое Оцко (L. Wielkie Oczko) приводит Szmeja (1987b) к выводу о численном преобладании зрелых особей над всеми другими стадиями развития («numerical dominance of mature individuals over all the other developmental stages», ibid, p. 537). По его данным, морфологически зрелые особи в различных популяциях оз. Доброгощ составляют 47,5-61,5\%, проростки - 10,5-18,2\%, ювенильные - 18,4-23,6\%, в оз. Великое Оцко - 52,6-77,8\%, 7,7-25,9\% и 9,4-20,7\%, соответственно. Генеративные особи - это всегда наименее многочисленная часть популяции (4,2-10,7\%, озеро Доброгощ и 1,6-5,1\%, в оз. Великое Оцко). Характеристика генеративного периода развития польским исследователем (Szmeja, 1987a) представлена кратко: «[генеративная стадия] встречается только у зрелых особей и длится от появ- ления цветоноса до его исчезновения〉 (ibid, p. 18). Между тем генеративный период развития у лобелии важен не только из-за возникновения и развития генеративных органов. Большое значение для будущего благополучия популяции этого растения имеет формирование у лобелии, в этот период развития, почек в пазухах самых верхних ассимилирующих листьев. Это будущие раметы (вегетативные диаспоры), обеспечивающие, в дальнейшем, вегетативное размножение особи и захват ею новых территорий. Szmeja (1987a) считает, что их наличие всегда сопровождается увяданием соцветия и всех листьев растения. Однако, по нашим сведениям (смотри выше, а также Lapirov et al., 2017), формирование латеральных почек у генеративных особей происходит в период завершения закладки терминального соцветия, либо на начальных этапах его развития. По-видимому, возможны оба варианта развития. В первом из них (увядание соцветия) полностью снимается так называемое апикальное доминирование - контроль верхушки побега над ростом пазушных почек (Cline, 1997, цит. по Dun et al., 2006). Во втором (начальные этапы, либо конечная стадия закладки соцветия) - развитие пазушных почек может встречаться и в присутствии сильной верхушки побега и модулироваться сигналами, поступающими из корня и стебля (Dun et al., 2006). Кроме того, имеющиеся отличия, возможно, связаны с различиями в географическом расположении изучаемых водоемов (польские озера в широтном плане располагаются южнее, чем тверские).

По своему внутреннему содержанию субсенильная (постгенеративная) стадия развития лобелии, описанная Szmeja (1987a, 1987b, 1994), вполне соответствует квазисенильному состоянию растений, рассмотренному нами выше. При этом мы согласны с мнением Smirnova et al. (1984, c. 224), что «вероятно, необходимо отличать истинную онтогенетическую старость от «старости» ценотической, которая представляет собой не что иное как квазисенильность». По нашим наблюдениям в изучаемых озерах особи лобелии образуют достаточно плотные скопления - «подводные ковры или луга» различной формы и степени протяженности (рис. 5). Формирование такой агрегированной структуры, по справедливому мнению Szmeja (1987b), является результатом борьбы растений за пищевые ресурсы и пространство и обеспечивает им более эффективную адаптацию к среде обитания. «В этой ситуации формирование агрегатов для L. dortmanna, а также для многих конкурентно слабых видов - наиболее выгодный адаптивный вариант, оправданный как с точки зрения защитных реакций на давление конкурентов (Zarzycк 1965, цит. по Szmeja, 1987b), тяжести условий жизни (Symonides 1979, цит. по Szmeja, 1987b), а также хода основных физиологических процессов» (ibid, p. 540). Szmeja (1987b, p. 541) отмечает, что «в случае L. dortmanna размер агрегатов и их плотность обратно пропорциональны интенсивности давления видов конкурентов и плодородия местообитаний. Это основные факторы, определяющие пространственную организацию популяций и социальный статус особей, живущих в нем».

Переход растений в квазисенильное состояние в компактных клонах способствует выживанию, а после гибели материнских растений, позволяет особям омолодиться и занять территорию вегетативным или семенным путем (Smirnova et al., 1984). Это так называемое циклическое развитие компактных клонов по типу: молодость - зрелость - старость - омоложение, дающее популяции возможность длительно удерживать занятое место в ценозе (ibid). Подобное развитие, по нашему мнению, характерно и для лобелии Дортманна. Так, в оз. Бельское изученные нами сообщества этого вида в тех же самых местообитаниях были отмечены первым автором еще в 1974 году, и, возможно, сформировались там еще раныше.

\section{Выводы}

Результаты исследований показали, что в олиготрофных озерах Тверской области онтогенез генеты лобелии Дортманна длится в течение пяти лет. В онтогенезе генеты L. dortmanna выделено и описано четыре периода (первичного покоя, прегенеративный, генеративный и постгенеративный) и девять возрастных состоя- 
ний особей (покоящиеся семена, проростки, ювенильные, молодые и взрослые вегетативные, скрытогенеративные, средневозрастные и старые генеративные и квазисенильные). Полная морфологическая дезинтеграция (вегетативное размножение) у лобелии наступает на пятом году жизни и приводит к образованию компактного клона.

Работа частично выполнена в рамках государственного задания ФАНО России (тема № АAАA-A18-118012690099-2).

\section{References}

Cenopopulyacii rastenij (osnovnye ponyatiya i struktura) [Cenopopulation of plants (basic concepts and structure)] (1976). Nauka, Moscow (in Russian).

Dun, E. A., Ferguson, B. J., \& Beveridge, C. A. (2006). Apical dominance and shoot branching. Divergent opinions or divergent mechanisms? Plant Physiology, 142, 812-819.

Lapirov, A. G., Belyakov, E. A., \& Lebedeva, O. A. (2017). Biomorphology and rhythm of seasonal development of the relic species Lobelia dortmanna in oligotrophic lakes of Tver region. Regulatory Mechanisms in Biosystems, 8(3), 349-355 (in Russian).

Lebedeva, O. A., \& Belyakov, E. A. (2016). Osobennosti prorastaniya semyan Lobelia dortmanna (Lobeliaceae) v usloviyah ehksperimenta [Features of seed germination of Lobelia dortmanna (Lobeliaceae) under experimental conditions]. Rastitelnye Resursy, 52(3), 375-380 (in Russian).

Lewicka-Rataj, K., Świątecki, A., \& Górniak, D. (2018). The effect of Lobelia dortmanna L. on the structure and bacterial activity of the rhizosphere. Aquatic Botany, 145, 10-20.
Markov, M. V. (2017). K izucheniyu polushnikovyh oligotrofnyh ozer Tverskoy oblasti: Fotosinteziruyushchaya biota kak indikator ih troficheskogo statusa [Research on the Isoetid oligotrophic Lakes in Tver region: Photosynthetic biota as their trophic state indicator]. Russian Journal of Ecosystem Ecology, 2(1), 1-19 (in Russian).

Nielsen, K. B., Kjøller, R., Olsson, P. A., Schweiger, P. F., Andersen, F. Ø., \& Rosendahl, S. (2004). Colonisation and molecular diversity of arbuscular mycorrhizal fungi in the aquatic plants Littorella uniflora and Lobelia dortman$n a$ in Southern Sweden. Mycological Research, 108(6), 616-625.

Pulido, C., Keijsers, D. J. H., Lucassen, E. C. H. E. T., Pedersen, O., \& Roelofs, J. G. M. (2012). Elevated alkalinity and sulfate adversely affect the aquatic macrophyte Lobelia dortmanna. Aquatic Ecology, 46(3), 283-295.

Savinykh, N. P., \& Cheryomushkina, V. A. (2015). Biomorphology: Current status and prospects. Contemporary Problems of Ecology, 8(5), 541-549.

Smimova, O. V., Chistyakova, A. A., \& Istomina, I. I. (1984). Kvazisenil'nost' kak odno iz proyavlenij fitocenoticheskoj tolerantnosti rastenij [Quasisenility as one of the manifestations of phytocoenotic plant tolerance]. Zhumal Obshchej Biologii, 45(2), 216-222.

Szmeja, J. (1987a). The seasonal development of Lobelia dortmanna L. and annual balance of its population size in an oligotrophic lake. Aquatic Botany, 28(1), 15-24.

Szmeja, J. (1987b). The ecology of Lobelia dortmanna L. II. Population structure and dynamics within a constant depth interval in oligotrophic lakes. Ekologia Polska, 35, 523-544.

Szmeja, J. (1994). Effect of disturbances and interspecific competition in isoetid populations. Aquatic Botany, 48, 225-238.

Woodhead, N. (1951). Biological flora of the British Isles: Lobelia dortmanna L. Journal of Ecology, 39(2), 458-464. 